\title{
The oil industry in our schools: From Petro Pete to science capital in the age of climate crisis
}

Accepted for publication in Environmental Education Research

Stuart Tannock, UCL Institute of Education

January 2020

Fossil fuel corporations play a significant role in promoting their interests in schools and other educational institutions, a practice that has recently been labelled as 'petro-pedagogy.' But this role goes beyond the production of the pro-petroleum and anti-science corporate propaganda that tends to attract the most critical attention. In this article, I present a case study of the involvement of BP, one of the world's largest fossil fuel corporations, in primary and secondary education in the United Kingdom. As practiced by BP, petro-pedagogy constitutes a core part of a corporate education reform network that, for the past decade, has focused on promoting a neoliberal model of STEM education in schools around the world. This model, based on corporate and capitalist interests, poses a significant threat to our collective efforts to tackle the global climate crisis.

Keywords: climate crisis, corporate education reform, fossil fuel industry, petro-pedagogy, science capital, STEM education

In 2017, the Center for Public Integrity in the United States published a widely circulated report on how the oil industry has established 'a pipeline to America's schools' (Zou 2017). Covering examples such as a program in Ohio that teaches students 'how to "frack" Twinkies using straws to pump for cream,' a national education program sponsored by BP and Shell that tells students 'it's too soon to tell if the earth is heating up, but "a little warming might be a good thing,", and other cases of 'oil industry puffery in the classroom,' the report focused on a children's book produced in 2016 by the Oklahoma Energy Resources Board (OERB), Petro Pete's Big Bad Dream. In this book, distributed for free to schools in Oklahoma, Petro Pete is a boy who attends Petroville Elementary School, where he and children like Sammy Shale and Oliver Oilpatch are taught by one Mrs Rigwell. One night, Petro Pete has a dream in which oil has disappeared from the world and discovers that life is a nightmare, as so many everyday objects around him are made from petroleum. When Pete wakes and realizes it was all just a bad dream, he is thrilled to find that 'everything is back to normal' as 'all of my petroleum by-products are back!' (Schaeperkoetter 2016, 38, 40). The story is just one of 'hundreds of pages' of oil industry friendly curricula, 'a speaker series and an afterschool program' produced by the OERB for use in Oklahoma schools. In reviewing this material, the report argues that it blurs the 'line between industry promotion and youth education,' particularly as it is produced by individuals without any scientific background or teaching experience, and is not reviewed by the state education department.

The Center for Public Integrity report is part of a small but growing literature on fossil fuel industry involvement in public education in the US and beyond - what Eaton and Day (2019) call 'petro-pedagogy,' defined as 'teaching practices and resources [that] work to centre, legitimize, and entrench a set of beliefs ... that align with the interests of fossil fuel industry actors' (1). The motivating concern of this literature is the central role that fossil fuel corporations have been playing, not just in causing global climate crisis, but in obstructing action and education that can address this crisis. To tackle the crisis of climate change, argue Eaton and Day (2019), among others, we 'need to dismantle the corporate power of the fossil fuel industries and their petro-pedagogy' (15). However, though critical attention to petro- 
pedagogy is vital, there is a danger of misrecognizing the role that the fossil fuel industry is currently playing in public education. The Center for Public Integrity report, for example, casts the fossil fuel industry as anti-science and anti-education, promoting climate change denialism and pro-petroleum rhetoric through industry sponsored curriculum in oil producing regions like Oklahoma. Fossil fuel corporations, of course, have a scandalous record of fostering anti-science, climate change denialist ideology, especially in the United States (Mann 2016); and there are numerous examples of industry propaganda that seek to convince children of the inherent goodness of fossil fuels. But this is just one mode of fossil fuel corporation involvement in education, and a narrow framing of the industry interests these corporations pursue through their educational engagements.

In this article, I present a case study of the involvement of BP, one of world's largest fossil fuel corporations, in primary and secondary level education in the United Kingdom, to illustrate the need for a broad understanding of the nature of contemporary petro-pedagogy. Far from being anti-science and anti-education, BP has successfully embedded itself at the heart of elite UK science and education policy and practice networks - in particular, networks focused on development and delivery of STEM (Science, Technology, Engineering and Mathematics) education. Rather than limiting itself to the narrow promotion of pro-petroleum rhetoric, BP has long seen its interests as being best served by the general promotion of probusiness practices and values throughout UK public education. Petro-pedagogy, in the case of $\mathrm{BP}$ at least, is best understood as a core component of a more extensive corporate education reform network that, for the past decade, has focused on promoting a neoliberal model of STEM education in schools around the world, based firmly on a 'corporate/capitalist vision for the purposes of schooling' (Hytten and Stemhagen 2019, 3; see also Coles 2018). For those concerned with the challenge of tackling global climate change, this model of STEM education should be as alarming as fossil fuel industry sponsored anti-science curriculum in the vein of Petro Pete. As Yanez et al. (2019) argue, the neoliberal STEM education model tends to encourage 'an uncritical embrace of underlying STEM narratives and purposes' that 'sustain unsustainable futures' $(1,8)$. While the focus of this article is on the UK, I argue briefly in the final section that oil majors like Exxon and Chevron, as well as BP, have been pursuing closely parallel corporate STEM education agendas in the United States.

\section{Research methods}

The empirical research for this article followed a model developed in two earlier studies of corporate promotion of enterprise education, and mining industry involvement in education in Canada (Sukarieh and Tannock 2009; Tannock 2010). This argues for the importance of adopting a broad research focus: investigating the historical emergence and development of corporate involvement in public education; resisting the temptation to center analysis only on the most egregious examples of corporate sponsored curriculum, in order to consider the full extent of corporate curricular and other involvement in education; and examining the overall body of corporate or industry engagement in formal and non-formal education, including but not only limited to direct presence in school classrooms. This approach seeks to correct a problematic tendency of research on corporate involvement in public education to be narrow in focus, "fragmentary" and "unsystematised" (Fontdevila, Verger and Avelar 2019, 2).

Research began with desk-based keyword searches of all the fossil fuel majors operating in the UK to identify links with both formal and non-formal education sectors. 
Once it became clear that the educational involvement of BP in the UK was by far the most extensive of any of these corporations, a decision was made to focus the case study on BP alone. Historical documents from the BP Educational Service, founded in the 1960s, were located in the UCL Institute of Education and British Library holdings. However, it was decided not to use the BP Archive at Warwick University: although this archive is housed in a public university, BP retains final control over who can access the Archive and what may or may not be published when using the Archive (email communication, BP Archive, September 2018).

Most of BP's current education curriculum is publicly available online. This curriculum was downloaded and subjected to critical reading that paid attention, in particular, to references to corporate, fossil fuel industry and general business sector interests. Online keyword searches were used to identify links between BP and education actors in the UK. Wherever links were identified, this was followed up by a focused investigation of these actors. For example, once a link between BP and the KCL/UCL science capital group (discussed below) was discovered, all institutional and academic outputs of this group were read closely, again paying attention to references to fossil fuel industry and general business interests. Conversely, websites and institutional documents (including annual reports etc.) of core third sector and government actors involved in UK STEM education were also searched to identify possible links with BP and other fossil fuel industry actors.

While this is a desk-based research study, a very small number (six) of qualitative interviews were conducted. When prospective interviewees were contacted, the focus of the research on investigating fossil fuel industry involvement in public education was made clear. Many requests for interviews were unsuccessful: a pattern also found in my previous studies of corporate involvement in public education. Four interviews were conducted with individuals involved in STEM education extra-curricular programs and teacher professional development across England; one interview was conducted with a journalist doing research on fossil fuel company involvement in UK education; and one interview was conducted with an individual involved as a direct partner in one of BP's educational projects. In general, it was found that interviews tended to confirm, but added little new information to, analyses developed from desk based research. In this article, these interviews are drawn on only occasionally, in instances where they provide suggestive commentary on some of these core analyses.

\section{Petro-pedagogy and corporate engagement with public education}

Critical attention to fossil fuel corporation involvement with public education is most extensive at the level of higher education, thanks to the rise of the fossil fuel divestment movement. Most of this literature focuses on understanding, and contesting, the financial ties that link universities to the fossil fuel industry, principally through fossil fuel investments held by university capital and endowment funds (Grady-Benson and Sarathy 2016; Healy and Debski 2017). A smaller body of research has sought to document links between universities and fossil fuel corporations in terms of sponsored research, industry-led teaching, building endowments, institutional partnerships and interlocking directorate networks (Carroll et al. 2018; Lander 2013; Muttitt 2003; Washburn 2010).

Attention to fossil fuel industry engagement in primary and secondary level education is far less developed. Manning (1999) writes of an 'environmental curriculum video produced 
by Shell Oil and concentrated heavily on the virtues of the internal-combustion engine while offering students pearls of wisdom like, "You can't get to nature without gasoline or cars,", and a lesson plan produced by Exxon called 'Scientists and the Alaskan Oil Spill' that 'praises the oil company's role in restoring the ecology of Prince William Sound while avoiding any discussion of what or who caused the Alaska oil spill in the first place.' Saltman and Goodman (2003) critique school science curriculum produced by BP Amoco as industry propaganda that promotes a false image of the company as a beneficent, responsible corporate citizen, while erasing its actual legacy of environmental, social and political wrongdoing and harm caused across the planet. Hodgkins (2010) analyses a video and high school teaching resource produced by an oil industry funded environment and energy group in Alberta, called The Amazing Athabascan Oil Sands, calling it 'corporate propaganda' filled with 'sanitized images and misleading claims' that portrays the 'Alberta oil sands story' as 'one of the most remarkable human adventures of our time' $(277,286)$. As with the Petro Pete report, these studies document the presence of blatantly pro-petroleum, anti-science and anti-educational rhetoric in fossil fuel industry sponsored school curriculum. Eaton and Day's (2019) study of petro-pedagogy offers an analysis of a different mode of fossil fuel industry school engagement. Though still focusing on industry sponsored curriculum in an oil producing region (Saskatchewan), Eaton and Day observe how this curriculum, rather than being clearly anti-science and anti-educational corporate propaganda, instead promotes a form of 'neoliberal environmentalism' that restricts 'the imagination of possible climate solutions to individual acts of conservation that fail to challenge the structural growth of fossil fuel production' and thereby works to 'insulate fossil fuel industries from criticism and dissuade young people from questioning or understanding the role of corporate power in the climate crisis' (2).

To broaden our analysis of petro-pedagogy in primary and secondary level education, it is useful to draw on literature on fossil fuel industry hegemony and corporatization of public education more generally. As Carroll et al. (2018) point out, in their mapping of 'carbon-sector reach' in civil society in Canada, interests pursued by fossil fuel corporations in their civil society engagements encompass both immediate and long-term agendas (425). 'Corporate influence is, at its core, geared toward protecting investments and profit streams, opening new fields for investments, and minimizing intrusions into profit,' the authors write: 'This entails different initiatives in different contexts, from tactical maneuvers to secure a specific objective (e.g., the green light for a new pipeline project) to the long game of cultivating a pro-business political and popular culture' (426). This range of interests is clearly visible in BP's educational work in the UK. BP's work with the UK education sector began in the 1960s with the creation of the BP Educational Service, motivated initially by an interest in workforce recruitment, and 'a desire to stem the drift from science by youngsters in schools' (Marsden 1991, 4). But this motivation soon widened. In the 1970s, BP grew concerned with what it saw as the 'poor understanding of and attitude towards industry' of British youth, and sought to use its position as one of the UK's most powerful corporations to influence education not just to serve the interests of BP but business overall:

BP's educational policy evolved during this time from the science and long term recruitment thinking towards a much broader emphasis on understanding industry and commerce.... [BP's] overall aim [was to] achieve developments in education which will help industry and commerce in general, and BP in particular, operate efficiently in the future... BP is in a position to take the lead ... as a model for others to follow.... We are the largest company in the UK financially and can exercise a corresponding level of influence in education. (Marsden 1983, 1, 2, 3) 
The 'founding principles' of BP's UK educational program, still operative today, state clearly that the aim of this program is to promote general industry interests in schools:

Industry has a chance to make itself heard in an area [education] in which it is frequently misunderstood and often viewed with suspicion and mistrust.... Industry not only achieves unity of purpose with the education system, but also in so doing may help remove in its own interests the bias against industry at present existing in schools and colleges. (Duffy 2018)

Petro-pedagogy, in other words, does not just involve the promotion of transparently propetroleum rhetoric, but encompasses more general educational interventions as well, that nonetheless support fossil fuel industry interests.

When considering fossil fuel industry intervention in public education, we also need to recognize that, as Fontdevila, Verger and Avelar (2019) note, corporations rarely adopt only a single role or strategy when seeking to shape educational policy and practice. Instead, the authors observe the 'diversification and hybridization of roles and strategies' adopted by corporate actors in the field of education, including 'knowledge mobilization, networking, engaging with grassroots, and sponsoring pilot projects' $(3,11)$. The 'most effective' corporate actors, the authors argue, 'in terms of [education] policy influence seem to be those that are able to invest in multiple strategies ... simultaneously' (11). Fontdevila, Verger and Avila also note the widespread practice of corporations supporting independent, third-party groups 'whose agendas are regarded as aligned to their own pro-market agenda' as an effective way to influence public education (8). If analysis of petro-pedagogy focuses only on a single curriculum resource, as has often been the case, then we risk misrepresenting and misunderstanding the overall nature of fossil fuel industry influence in education. In the case of BP, there has been a large investment in developing sponsored curriculum materials; but the company has also engaged extensively in networking; and through these policy and practice networks, identifying and sponsoring third party actors who carry out education work allied with its own interests and agendas.

Finally, when fossil fuel corporations seek to influence public education in the UK, US and elsewhere, they do so alongside a wide range of other corporate actors in a sector that, for decades, has been deliberately opened to business intervention by political and education elites. This is the phenomenon that has been extensively studied and analysed as a process of neoliberalization of public education (Au and Ferrare 2015). Neoliberalism as a term is widely recognized to be a "loose and shifting signifier": just as petro-pedagogy has different modes of operation, so too has the neoliberalization of education led to different kinds of reforms and practices in different time periods and contexts (Brown 2015, 20). With this caveat in mind, neoliberalism may be defined both as a "political project" and as "an ensemble of economic and social policies, forms of governance, and discourses and ideologies" that promotes a model of market fundamentalism directly driven by the interests of economic elites in the capitalist economy (Hursh, Henderson and Greenwood 2015, 300; Lipman 2011, 6; see also Harvey 2005). In education, the neoliberal model has seen a vastly expanded role for private sector actors in education provision and education policy networks, an introduction and expansion of market practices and discourses to the sector, and a transformation of the nature and purpose of education "from a public to a private good, [and] from a service to a commodity" (Ball 2016, 1049). Education increasingly is oriented to the "production of 'human capital' ... and meeting the needs of the economy, rather than ... serving the social good or meeting collective needs of communities" (Au and Ferrare 2015, 6); and "knowledge, thought and training are valued and desired almost exclusively for their contribution to capital enhancement" (Brown 2015, 177; italics in original). With 
neoliberalization, a corporate education reform network has come to play a direct, central role in guiding a continuous restructuring of the public education sector at the local, national and global levels (Au and Ferrare 2015; Ball and Junemann 2012; Simons, Lundahl and Serpieri 2013).

For the last decade, one of the central concerns of this network of corporate education reform actors in the UK, US and elsewhere has been the heavy promotion of a neoliberal model of STEM education (Coles 2018; Sharma 2016; Zeidler 2016; see also Andrée and Hansson 2019). This model has at least three core characteristics: STEM education is claimed to be a national priority, of greater value and importance than other types of education; the value and importance of STEM education is seen in terms of its contribution to national economic competitiveness and individual economic mobility in the job market; the model also promotes an 'acritical celebration of STEM education' that positions students 'to see advancement in STEM fields as apolitical and inherently good,' rather than helping them 'question problematic scientific advances' or 'challenge corporate practices' (Hytten and Stemhagen 2019, 3, 11; see also Yanez et al. 2019; Zouda 2018). While fossil fuel corporations are not the only corporate actors involved in promoting this agenda, they often play a lead role, partly due to their enormous economic power and strategic importance (Coles 2018; Kennedy-Salchow 2017). The threat posed by petro-pedagogy to collective efforts to tackle the global climate crisis may actually lie less in its production of antiscience, anti-education corporate propaganda, and more in its promotion of a model of science and education that is wedded so firmly to business and market interests.

\section{BP sponsored curriculum in schools}

The most widely studied mode of petro-pedagogy is fossil fuel industry sponsored curriculum, which is something that BP has been producing for decades. Back in 1974, BP produced a booklet for UK schools called Children and Oil that, much like the Petro Pete story, sought to foster a strong feeling of oil dependency and appreciation among teachers and children. 'In our modern society oil is of vital importance,' the introductory note for teachers states: 'If you were to make a list of those things which depend on oil, ... it would be so extensive you might wonder how we managed for so long without oil'(Horn 1974, 4). The booklet suggests classroom activities such as making an 'oil display' of 'everyday products made or supported by oil,' writing about 'life without oil,' constructing model drill bits and oil rigs, and fostering an interest in oil across the whole school curriculum, from math to history to creative writing. Today, the BP Educational Service offers hundreds of free online teaching resources for use in schools with students aged 4-19 in the subjects of science, geography, business, design and technology. These cover not just topics directly related to the oil industry, but everything from learning about the lives of famous scientists, to how to design a guitar, identify different species of trees, understand how frogs, horses and other animals care for their young, and so on (BP 2019b).

In assessing this mass of oil industry sponsored curriculum, two considerations are important. First, is the question of ideological framing and educational value. BP notes that its curriculum (unlike Petro Pete) is developed by and with teachers and education researchers to fit the UK National Curriculum: it would be inaccurate to dismiss it altogether as nothing more than corporate propaganda. Some of the BP curriculum has no obvious link with either fossil fuel industry or general business interests. Nonetheless, regardless of curricular focus, BP's curriculum provides easy advertising access to children in schools, as it 
is almost always plastered with BP logos and corporate colors. As the media group DeSmog argues, this allows a company with a poor environmental, health and safety, and human rights record to pose as a responsible and ethical corporate citizen, and constitutes part of a deliberate PR strategy by BP to maintain its 'social license to operate' (Hope 2017). BP, it needs to be remembered, despite claiming to support climate change policy: continues to invest billions in opening up new fossil fuel reserves (Bowers and Davies 2015; Rowell 2018); has been called 'Europe's fiercest corporate opponent of action on climate change' due to its lobbying against proposed EU climate change regulations (Neslen 2015; see also Neslen 2016); is a member of 'trade associations ... that spread disinformation about climate science and seek to block climate action' (Mulvey 2018b); actively lobbied in the US for the 'repeal or rollback' of methane emission regulations (InfluenceMap 2019); and most recently, spent millions of dollars to defeat a ballot initiative in Washington State to institute a carbon fee (Mulvey 2018a).

Further, some of BP's curriculum does directly promote industry interests. $B P$ in Business, for example, a secondary curriculum unit, encourages students to view the world from BP's perspective, asking students to think about how to improve BP's revenue stream, raise cash for BP, and evaluate BP's financial performance (BP 2008b). A unit on BP and the Environment tells students that 'BP has a big responsibility ... to ensure security of [energy] supply ... [and] make sure it is always able to provide enough oil and gas for its customers,' a responsibility shaped by 'legal conditions to which it must adhere': the message is that attempts to reduce oil and gas extraction and distribution are irresponsible and possibly illegal (BP 2008a). The same unit claims 'BP is investing large sums of money in alternative energy technologies,' when the company has been widely criticized for not investing extensively in low carbon energy (BP 2008a; Vaughan 2018). BP's climate change curriculum works to shift attention away from its own responsibility for climate change (and makes no mention of its efforts to block and undermine climate change legislation), focusing instead on other factors such as population growth, poor building design, deforestation and farming (BP 2007; Hope 2017a). BP tells students 'it's difficult to decide who is responsible' for anthropogenic climate change, and insists that 'fossil fuels will remain an important energy source until they finally run out' (BP 2007, 2009a). In general, the closer that BP's school curriculum comes to its own business interests, the more ideologically problematic it tends to be.

A second question is how widely used oil industry curriculum like that produced by $\mathrm{BP}$ is in UK schools. According to BP, this curriculum is virtually everywhere: $81 \%$ of UK schools are claimed to be registered with the BP Educational Service, and BP curriculum was allegedly used by 80,000 teachers in $57 \%$ of UK secondary schools, reaching 1.4 million students in the three years between 2014 to 2017 alone (BP 2019a). Such figures are remarkable; but also need to be taken with a grain of salt, as they are self-reported. In the small number of interviews conducted for this study with school science teacher trainers, one said they had never encountered BP curriculum in UK schools, one said they had only rarely encountered BP curriculum, while two said such curriculum was widespread. One challenge that BP faces in its production of sponsored curriculum is that there are some schools, teachers and groups who won't use its materials because they are produced by a fossil fuel corporation (e.g., Campaign Against Climate Change 2019) - a liability that might be expected to grow in the wake of mass school climate strikes in the UK. On the other hand, in an environment in which many teachers continue to find themselves pressed for time and resources, the often attractively packaged and effectively designed curriculum resources offered by BP may well be widely embraced. As one teacher trainer admitted, even though 
she felt teachers are not doing enough to 'interrogate the industry resources' they use in the classroom, these resources are seductive: BP 'have some [dinosaur] fossil [teaching] resources which are highly recommended and people love them' (personal interview, March 2019).

\section{BP and STEM education policy and practice networks}

A second mode of petro-pedagogy is through networking with other education policy and practice actors, and in this, BP has been highly successful, particularly in the realm of STEM education. To illustrate: in 2016, the Royal Academy of Engineering produced a report on The UK STEM Education Landscape that counted more than 600 organizations that are involved in some way with STEM education in the country (Morgan and Kirby 2016). A central aim of the report was to show the 'highly complex' and fragmented nature of UK STEM education, due to the sheer number of organizations involved. Yet, the report also helps to show how, in certain respects, STEM education provision in the UK is not fragmented at all. The STEM Education Landscape report highlights and names just over 100 key STEM education organizations working in the UK (see Figure 1): of these, at least 62\% have links with the fossil fuel industry, through financial, personnel and/or institutional partnership ties (for STEM diversity groups, activity providers, teacher support, museums and discovery centres, and science community organizations, the figure of fossil fuel industry links rises to $82 \%$ ) (6). BP alone has links with $42 \%$ of the named STEM education organizations, while Shell and Exxon Mobil also have a strong network presence.

\section{[ Insert Figure 1 about here ]}

\section{Figure 1: UK STEM Education Landscape (from Morgan and Kirby 2016, 6)}

From science fairs and competitions to science museums to science teacher training and support, big oil in the UK plays a key role. The Royal Academy of Engineering itself offers an example of the extent of fossil fuel industry-STEM education networks in the country. Not only was BP one of just two corporations directly consulted for the STEM Education Landscape report, the Academy President, Dame Ann Dowling, is a non-executive director of BP; while the former CEO of BP, Lord Browne, was Academy President from 2006 to 2011 (Royal Academy of Engineering 2019b). The Academy runs the 'This is Engineering' campaign to introduce students to engineering in partnership with BP and Shell, and the 'Connecting STEM Teachers' program 'to create a national network of support for teachers across all STEM subjects' in partnership with Shell and Petrofac (Royal Academy of Engineering 2019a, 2019c) (see Parkinson and Wood 2019 for a similar argument about the involvement of fossil fuel corporations with professional science and engineering organizations in the UK).

While BP has actively sought direct involvement in UK STEM education policy and practice, its influence in this (and many other domains) has also been fully embraced by the UK state. For decades, the UK government, like elsewhere, has promoted STEM education for its economic and business value; and, as a corollary, pushed to increase direct business involvement in STEM education (Tomei, Dillon and Dawson 2015, 161). 'Business relies on world-class skills to innovate and compete,' wrote Lord Sainsbury (2007) in his review of science policy for the UK Treasury: 'It is essential that we raise the level of our science, technology, engineering and mathematics skills' (95). 'It is vital to our economy and to the 
country's prosperity that we maintain and develop our science base,' agrees the UK Department for Education and Skills $(2006,3)$. BP's involvement with UK STEM education policy is embedded within a far more extensive deep engagement with the UK state. A 2015 Guardian investigation of BP's links with the UK government quotes a former UK official as saying: 'The presumption that the British government should have an intimate relationship with big British multinationals especially BP and Shell was in the air you breathed' (Lawrence and Davies 2015). Ties between BP and the New Labour government were so close the company was "nicknamed "Blair Petroleum,", after Prime Minister Tony Blair (Coates 2007). In 2009, when the Labour government wanted a review of higher education funding in the UK, it asked Lord Browne, the former CEO of BP, to lead the process (Garner 2009). In 2010, the Coalition government appointed Browne to be "'lead non-executive director" at the Cabinet Office,' a role in which he oversaw the recruitment of 68 business executives to sit on new boards at 17 government departments: these executives could 'enjoy access to the most senior decision makers' and 'inject their own views and priorities into the policy process' (Wilks 2015, 31).

An illustration of how BP's engagement with UK STEM education policy and practice networks operates can be seen in the development of continuing professional development (CPD) programs for STEM school teachers in the UK over the past decade. In 2006, the government centralised STEM education provision in the UK with the appointment of a National STEM Director to oversee the reorganisation of STEM learning resources into a single physical and online hub and spoke network (DfES 2006). Today, this has evolved into STEM Learning, the country's largest provider of CPD for STEM school teachers (claiming to reach all secondary and $80 \%$ of primary schools) and largest center for STEM education and careers guidance programming and curriculum resources (Morgan and Kirby 2016, 27; STEM Learning 2019a). In 2008, to support and develop this STEM learning centre and network, the Wellcome Trust (the UK's largest charitable foundation) took lead on creating Project ENTHUSE, 'a unique partnership between business, Government and the Wellcome Trust' that provided an initial $£ 30$ million 'to retool our teachers through a programme of professional development in science underpinned by industrial experience' (Wellcome 2008) (see Figure 2). BP was a founding member of Project ENTHUSE: Wellcome's Chairman at the time, Sir William Castell, was also senior independent director and Safety, Ethics and Environment committee chairman at BP (three years later, Castell was forced to step down from these roles by BP stakeholder opposition for his role in the 2010 BP Deepwater Horizon disaster) (BP 2009b; Gosden 2012).

\section{[ Insert Figure 2 about here ]}

\section{Figure 2: STEM Learning and Project ENTHUSE in the UK}

As a result of these developments, BP now has a role at the heart of STEM school teacher CPD in the UK. BP's UK Head of Community Development sits on the governing board of STEM Learning and is trustee of Project ENTHUSE (STEM Learning 2019b); he also was a member of the Department for Education Review Panel to evaluate the UK's National Network of Science Learning Centres in 2012 (DfE 2012). Through these ties, BP is able to have a direct say in UK STEM education provision, working to ensure that STEM education in the country serves the interests of BP and UK business. As Fontdevila, Verger and Avelar (2019) note, in this context of corporatization of education, 'the delimitation between the public and the private sphere in policy processes [is] increasingly difficult to establish' (11) - and fossil fuel corporation presence is not always easy to identify, let alone 
contest. BP, as noted above, has an agenda to promote close business engagement with schools in the UK (BITC 2018). In 2016, BP's Head of Community Development wrote the introduction for a report produced by Project ENTHUSE on exactly this topic, titled Why Your Business Should Go Back to School (EdComs 2016). The report calls for 'more businesses to bring real-world context and inspiration into the classroom,' to address the problem 'that not enough young people are choosing to study STEM-related subjects after the age of 16,' which 'is limiting business growth and having a negative impact on the economy' $(2,3)$. Thoughout, the focus is on enabling students to grasp the pivotal role of STEM education for jobs, business, industry and the economy: concern with issues of social and environmental justice is marginal. One way the report says that 'business could make a real difference' is by providing examples from the business world that show 'the positive impact of STEM on humanity' (9). Hytten and Stemhagen $(2019,3,11)$ argue that the neoliberal model of STEM education is marked by an 'acritical celebration of STEM education' and a (not so) 'hidden curriculum of STEM' of supporting 'a corporate/capitalist view for the purpose of schooling'. The Project ENTHUSE report clearly articulates just such a neoliberal model of STEM education.

\section{BP funded education research: The case of science capital}

Through engaging with STEM education policy and practice networks, BP also seeks out and supports third party actors whose STEM education work aligns with its interests. In 2013, BP provided $£ 4.3$ million to fund the five year Enterprising Science project, a partnership with King's College London (and later University College London), the Science Museum Group, and the National STEM Learning Centre. The aim of the project, billed as the 'largest UK-wide science learning programme of its kind,' was to refine and operationalize the concept of 'science capital' that had been coined by the academics on the project, and use this concept to develop formal and non-formal science teaching approaches that would effectively engage 'students from all backgrounds with science, particularly focusing on those from disadvantaged schools and communities' (BP 2013; UCL 2019). Science capital is a term used to refer to 'all the science-related knowledge, attitudes, experiences and resources that you acquire through life;' and 'the more science capital a young person has, the more likely s/he is' to pursue post-compulsory science education and careers in science (Enterprising Science 2016, 2). Enterprising Science was a high profile, elite partnership that produced over a dozen articles in academic journals, won an impact award from the British Educational Research Association, and was endorsed by the UK Ministers for Education, Universities and Science (BP 2013; UCL 2019).

BP not only funded Enterprising Science, but was an active promoter, embracing the project's concept of science capital as a frame for its own work in STEM education. BP's UK Head of Community Development claims to have been a hands-on project leader throughout the Enterprising Science project (Duffy 2018); and BP even loaned Enterprising Science its corporate color scheme of different hues of green for its logo (UCL 2019). BP hosts science capital reports, videos, quizzes and guides on its corporate website (BP 2019c). In testimony to the UK House of Commons Science and Technology Committee, BP (2017) stated that:

we believe the concept of 'science capital' ... provides the best current model for understanding and influencing the choices made by young people [to take up STEM courses and careers].... BP aims to build up what has been termed 'science capital' in young people.... We are investing significantly in developing practical approaches that build science capital and are taking them to scale through our range of national partnerships and collaborations. 
In 2018, science capital became the conceptual frame for a renewed partnership between BP and the Science Museum Group (with the lead UCL science capital academic acting as official adviser) to launch an Academy of Science Engagement in London and Manchester (Science Museum Group 2019b). The aim of the Academy is to provide 'science engagement training and resources for teachers, museum and STEM professionals' (Science Museum Group 2019a). In 2019, BP supported a partnership programme between the Science Museum Group and the UK Association for Science and Discovery Centres to extend the "Science Capital in Practice" approach to fifteen other science centres and museums around the UK (UKASDC 2019). This ongoing partnership between the Science Museum Group and BP has been repeatedly condemned by climate crisis activists, including many of the country's leading climate scientists (Culture Unstained 2018).

Why would a fossil fuel corporation like BP find an academic concept like social capital to be so appealing? After all, the academics who developed the concept are not in any discernable way 'pro-petroleum,' derive their model from the work of French sociologist Pierre Bourdieu, and are primarily concerned with issues of race, class and gender inequality in access to science (Archer et al. 2015, 2018). In part, there is an obvious PR gain for a company widely condemned for it role in driving climate change, obstructing climate change action, and inflicting environmental and human rights harms worldwide to be seen supporting high quality academic research focused on issues of school improvement, and race, class and gender justice. But the concept of science capital also benefits BP (and other corporations) in three interconnected ways. First, the science capital approach provides a clear call, or at least opening, for schools to work closely with business (indeed, Enterprising Science models this in its own partnership of universities, museums and industry). To increase the science capital of their students, schools are encouraged to develop links with institutions where science is used regularly, foster student awareness of how science learning 'can lead to a wide range of jobs,' and create opportunities for students to meet with people 'who work in science-related roles' (Enterprising Science 2016, 3). The Project ENTHUSE report, Why Your Business Should Go Back to School, invokes the concept of science capital as a key justification for why business should have a central role in school STEM education (EdComs 2016, 5-6). As one teacher trainer worries, schools are opening their classrooms to 'scientists' in the name of growing science capital, but often without asking hard questions about what these 'scientists,' some of whom work in fossil fuels or weapons manufacturing, actually do to the world: 'Teachers are like, "Let's get a scientist in, we're hitting a little bit of science capital, we've exposed the children to some real scientists," ... [but] who are they, where are they coming from and what message are they giving?' (personal interview, May 2019).

Second, the science capital approach tends to adopt a business framework for promoting the value of STEM education. Enterprising Science publications repeatedly emphasize the need to increase STEM participation in order to improve 'national economic competitiveness' (e.g., Archer et al. 2015, 926). Here, the name of the partnership, 'enterprising' science, is relevant. While Enterprising Science researchers insist they are principally concerned with promoting 'social justice,' this concern is largely subsumed within economic, labor market relationships, focused on addressing inequality of access of women, working class and some ethnic minority groups to post-secondary science and science careers. 'In terms of social justice,' write King et al. (2015), for example, 'science qualifications can 'open doors' to a range of careers' and 'science graduates are likely to earn more in their lifetimes than non-science graduates' (2988). 'Our position is ... informed by the strategic value of science qualifications in educational and labour markets,' write DeWitt, 
Archer and Mau (2016), and 'the wage premiums often commanded by science qualifications' (2432). 'The hidden - and often not so hidden - curriculum' of neoliberal models of STEM education, as Hytten and Stemhagen (2019) note, 'is that schooling should help individuals leverage their individual skills to get a lucrative job; to "acquire the ethos of the market"' (11). This over-riding vocational focus, along with an embrace of "the ethos of the market', may be found throughout the academic writings of the Enterprising Science research group.

The raises the third value of the science capital concept for BP: as currently framed, the concept tends to ignore critiques of how science and technology are used by fossil fuel corporations (or other entities). Science capital is a concept derived from Bourdieu's concept of cultural capital: but unlike Bourdieu, Enterprising Science authors do not address whether or how promotion of science capital in contemporary society may be culturally arbitrary, or if it imposes symbolic (or indeed, physical or economic) violence (Williams and Choudry 2016). To use Bourdieu's terminology, the focus of science capital research is on the 'field' of the school classroom, where researchers make important critiques of how the already existing science capital of women, working class and ethnic minority students is often systematically misrecognized and denigrated (Archer et al. 2018). However, the approach tends not to look critically at the wider 'field' of science capital in capitalist industrial production: to ask whether, for example, use of scientific knowledge and skill by a corporation like BP contributes to global well-being or harm. Science capital researchers are highly critical and political in raising essential questions about whose science capital is recognised or ignored, or about who is given or denied access to acquiring science capital, in terms of race, gender and class identities. But the concept of science capital itself tends to be constructed in an essentially apolitical and acritical manner as being inherently good, an additive resource or benefit that one can have either more or less of. Science capital, states the Science Museum Group (2019b), 'is a measure of your engagement or relationship with science, how much you value it, and whether you feel it is 'for you' and connected with your life.' What, then, of the climate crisis activist who does not particularly 'value' the scientific activities of a corporation like BP, or see these activities as being 'for them?' For

Enterprising Science researchers, the question of whether science capital might sometimes be a '"bad" thing,' once raised, is quickly dismissed (Archer et al. 2015, 943). Science capital, in other words, provides a perfect conceptual framework for and justification of the neoliberal model of STEM education that has been so widely promoted by BP and other corporate education reformers in the UK and elsewhere.

\section{The fossil fuel industry - STEM education connection in the United States}

Climate crisis activists have sometimes noted a difference in approach between fossil fuel industry actors in the UK and EU as compared with the US: they were earlier to move away from strong forms of climate change denialism, and find alternative ways to contain environmentalist and scientific knowledge and action that threaten industry interests (Hope 2017). However, when it comes to petro-pedagogy and the promotion of the neoliberal model of STEM education, there are currently strong parallels between the UK and US. Like BP in the UK, ExxonMobil and Chevron (as well as Conoco and BP) have both taken lead roles in STEM education policy and practice networks in the United States (Kennedy-Salchow 2017).

Both ExxonMobil and Chevron sponsor and partner with dozens of STEM education organizations throughout the US, focusing on STEM teacher training and professional 
development, raising STEM proficiency among primary and secondary students, and targeting increased STEM engagement for female, racial and ethnic minority students. This includes work with groups such as the STEM Education Coalition, National Math and Science Initiative, Project Lead the Way, National Science Teachers Association, National Academy of Engineering, Teach for America, Teach for All, and numerous other universities, school districts, state agencies, corporations and nonprofit organizations. As with BP's work with science capital in the UK, a common petro-pedagogy strategy for both corporations is to identify third party STEM education organizations that are effective at the local level, and that are aligned with corporate and industry interests and agendas, and then provide funding and support to scale these up to the national level (Berkowicz and Myers 2015; Chevron 2018a, 2018b; ExxonMobil 2018; Nelson 2018).

All of this work is committed to promoting a neoliberal model of STEM education. 'Education is a fundamental building block of individual opportunity and economic growth,' ExxonMobil (2019) declares: 'STEM skills are critical to ensuring today's students are prepared for the jobs of the $21^{\text {st }}$ century.' A study of the national UTeach program, supported by ExxonMobil and the National Math and Science Initiative and focused on recruiting and training new STEM teachers, found a general neglect of critical social justice concerns in its STEM teacher training model (Kelly 2017). Coles (2018), in his recent book Miseducating for the Global Economy, likewise critiques the Chevron supported Project Lead the Way, a national STEM education non-profit organization, for producing school curriculum that promotes 'uncritical acceptance of the dominant economic-political order' and facilitates 'classroom silence and confusion about the contemporary global economy and its impact on humanity’ (13-14).

\section{Conclusion}

Since early 2019, thousands of students from schools across the UK have been going on a series of one day school climate strikes; worldwide, millions of students have also struck for climate action (Klein 2019). One of the demands of striking students in the UK is that 'the national curriculum is reformed to address the ecological crisis as an educational priority' (UK Student Climate Network 2019). Students in England note that, of the ten thousand lessons they receive during compulsory education, less than ten focus on climate change 'and there's not a single lesson telling us how to address it'; Teachers for Climate Truth, a group supporting the striking students, complained to the UK Department for Education that climate change is 'little more than a footnote in our national curriculum - a vague and marginal concern' (Ronan 2019).

Such views are supported by a wider academic literature. In England, recent Conservative led governments have removed 'environmental education ... as an explicit value underpinning the National Curriculum,' cut funding and abandoned statutory targets for developing sustainability education in schools (Glackin and King 2018, 3; Lovett et al. 2018). When climate change is taught, it is usually framed as physical science rather than social justice education, and emphasis is placed on individual behavior change not collective action, as consideration of the core 'social, political and economic processes that need to be transformed' to halt climate change are neglected (Waldron et al. 2019, 895). Schools' ability to address climate change is further limited by an emphasis on national assessment regimes, and orientation to national economic competitiveness and growth imperatives (Henderson et 
al. 2017). As Orr $(2004,27)$ writes, many schools 'are still educating the young as if there were no planetary emergency.'

What the school climate strikers are coming up against is the neoliberal model of STEM education that has been promoted by business and political elites in the UK and elsewhere for the last decade. As this article has sought to show, fossil fuel corporations such as BP have been at the heart of promoting this model of STEM education, for they recognize that it serves their own corporate and industry interests. Contesting this model of STEM education, Sharma (2016) warns, is not going to be easy, partly because of the corporate education reform network that works incessently to promote it:

Educators will need to keep in mind that behind the hegemony of [neoliberal] STEM education lies a big and powerful actor-network that exists to support the hegemonic practices, institutions and positive knowledges associated with [neoliberal] STEM education. (48)

This brings us back to the argument of Eaton and Day (2019) that began this article: to tackle the crisis of climate change, we 'need to dismantle the corporate power of the fossil fuel industries and their petro-pedagogy' (15). Doing this, however, will require a far different model of STEM education: one that can help students 'understand how manipulative politics, economic power and myth making PR are subverting public democratic will,' and encourage 'young people to apprentice as critical scientific policy analysts,' and 'create innovative counter-narratives to the old dysfunctional stories of intensifying carbon dependence' (Elshof 2011, 15). This task may seem overwhelming, but alternative models for such education already exist. Hytten and Stemhagen (2019), for example, call for a return to democratic models and purposes of education, both in schools in general and STEM education in particular. Yanez and her co-authors $(2019,2)$ seek to "recompose science education and learning in an explicitly critical way," by drawing on the insights of "critical sustainability studies" and "production pedagogy." Henderson (2019) argues cogently for teaching climate change and other scientific topics through a pedagogical lens that explicitly acknowledges that social, political and economic "power matters." Others working in the field of climate change education are turning increasingly to models of "transgressive" and "transformative" pedagogy and learning (Busch, Henderson and Stevenson 2018; Peters and Wals 2016; Selby and Kagawa 2018). It takes only a glance at what are now becoming daily headlines of growing environmental - not to mention political and economic - crises worldwide to be given a sharp reminder of just why the work of radically shifting direction in STEM education, and all other types of education, is today so vitally important.

\section{References}

Andrée, M., and L. Hansson. 2019. "Industrial Actors and Their Rationales for Engaging in STEM Education.” Journal of Curriculum Studies. DOI: 10.1080/00220272.2019.1682055. Archer, L., E. Dawson, J. DeWitt, A. Seakins, and B. Wong. 2015. “'Science Capital': A Conceptual, Methodological and Empirical Argument for Extending Bourdieusian Notions of Capital Beyond the Arts." Journal of Research in Science Teaching 52(7): 922-948.

Archer, L., E. Dawson, J. DeWitt, S. Godec, H. King, A. Mau, E. Nomikou, and A. Seakins. 2018. 'Using Bourdieu in Practice? Urban Secondary Teachers' and Students' Experiences of a Bourdieusian-Inspired Pedagogical Approach." British Journal of Sociology of Education 39(3): 283-298. 
$\mathrm{Au}, \mathrm{W}$., and J. Ferrare. 2015. "Introduction: Neoliberalism, Social Networks, and the New Governance of Education." In Mapping Corporate Education Reform, edited by W. Au and J. Ferrare, 1-22. New York: Routledge.

Ball, S. 2016. "Neoliberal Education? Confronting the Slouching Beast." Policy Futures in Education 14(8): 1046-1059.

Ball, S., and C. Junemann. 2012. Networks, New Governance and Education. Bristol: Policy Press.

Berkowicz, J., and A. Myers. 2015. "Chevron's Investment in STEM Education.” Education Week. 10 March.

BITC - Business in the Community. 2018. "Why Should We Invest in Teachers?" 19 January. https://www.bitc.org.uk/media-centre/blogs/why-should-we-invest-teachers.

Bowers, S., and H. Davies. 2015. "Oil Company Bosses' Bonuses Linked to \$1tr Spending on Extracting Fossil Fuels." Guardian. 25 May.

BP. 2007. Climate Change Student Booklet. London: BP.

BP. 2008a. BP and the Environment. London: BP.

BP. 2008b. BP in Business. London: BP.

BP. 2009a. Carbon Capture and Storage. London: BP.

BP. 2009b. "Inspiring Tomorrow's Bright Sparks.” BP Magazine. Issue 1. London: BP.

BP. 2013. "Cross Industry Partnership to Deliver Ground Breaking UK-wide Science Learning Programe." 4 July. https://www.bp.com/en/global/corporate/news-andinsights/press-releases/cross-industry-partnership-to-deliver-ground-breaking-uk-widescience-learning-programme.html.

BP. 2017. Written Evidence Submitted by BP plc. 18 January. House of Commons Science and Technology Committee.

http://data.parliament.uk/writtenevidence/committeeevidence.svc/evidencedocument/scienc e-and-technology-committee/closing-the-stem-skills-gap/written/45196.html.

BP. 2019a. "BP Celebrates 50 Years Supporting Education in the UK." https://bpes.bp.com/news/50-years-bpes.

BP. 2019b. "BP Educational Service.” https://bpes.bp.com.

BP. 2019c. "Science Capital and the STEM Skills Gap." https://www.bp.com/en_gb/unitedkingdom/home/community/stem-education/stem-skills-gap-science-capital.html.

Brown, W. 2015. Undoing the Demos: Neoliberalism's Stealth Revolution. Brooklyn: Zone Books.

Busch, K., J. Henderson, and K. Stevenson. 2019. "Broadening Epistemologies and Methodologies in Climate Change Education Research." Environmental Education Research 25(6): 955-971.

Campaign Against Climate Change. 2019. "Climate Change in Schools." https://www.campaigncc.org/schoolresources.

Carroll, W., N. Graham, M. Lang, and Z. Yunker. 2018. "The Corporate Elite and the Architecture of Climate Change Denial." Canadian Review of Sociology 55(3): 425-450.

Chevron. 2018a. Empowering the Workforce of the Future.

https://www.chevron.com/stories/empowering-the-workforce-of-the-future.

Chevron. 2018b. STEM Education Partners and Programs. https://www.chevron.com//media/chevron/PDF-Reports/Corporate-Responsibility/education-partners-programs.pdf.

Coates, S. 2007. "BP was Nicknamed 'Blair Petroleum." Times. 2 May.

Coles, G. 2018. Miseducating for the Global Economy. New York: Monthly Review Press.

Culture Unstained. 2018. Complaint to the Science Museum Group. London: Culture Unstained.

DeWitt, J., L. Archer, and A. Mau. 2016. "Dimensions of Science Capital." International Journal of Science Education 38(16): 2431-2449. 
DfE - Department for Education. 2012, Quinquennial Review of the National Network of

Science Learning Centres. London: DfE.

DfES - Department for Education and Skills. 2006, The STEM Programme Report. London: DfES.

Duffy, I. 2018. "Personal Reflections on the Last Five Years of Enterprising Science."

LinkedIn. 13 May. https://www.linkedin.com/pulse/personal-reflections-last-five-yearsenterprising-science-ian-duffy/.

Eaton, E., and N. Day. 2019, "Petro-Pedagogy: Fossil Fuel Interests and the Obstruction of

Climate Justice in Public Education." Environmental Education Research. DOI: 10/1080/13504622.2019.1650164.

EdComs. 2016. Why Your Business Should Go Back to School. London: Project ENTHUSE.

Elshof, L. 2016. "Can Education Overcome Climate Change Inactivism." Journal for Activism in Science and Technology Education 3(1): 15-51.

Enterprising Science. 2016. Science Capital Made Clear. London: KCL.

ExxonMobil. 2018, United States Education Initiatives.

https://corporate.exxonmobil.com/Community-engagement/STEM-education/United-

States-education-initiatives.

ExxonMobil. 2019, Growing STEM Talent, Developing STEM Teachers.

https://www.forwardontalent.org/stories/exxonmobil/.

Fontdevila, C., A. Verger, and M. Avelar. 2019, "The Business of Policy: A Review of the

Corporate Sector's Emerging Strategies in the Promotion of Education Reform." Critical

Studies in Education. DOI: 10.1080/17508487.2019.1573749.

Garner, R. 2009. "Lord Browne Returns to Public Life to Chair Student Fees Review."

Independent. 9 November.

Glackin, M., and H. King. 2018. Understanding Environmental Education in Secondary

Schools in England. London: KCL.

Gosden, E. 2012. "BP Safety Committee Chairman Sir William Castell to Leave." Telegraph.

3 February.

Grady-Benson, J., and B. Sarathy. 2016. "Fossil Fuel Divestment in US Higher Education." Local Environment 21(6): 661-681.

Harvey, D. 2005. A Brief History of Neoliberalism. Oxford: Oxford University Press.

Healy, N., and J. Debski. 2017. "Fossil Fuel Divestment: Implications for the Future of

Sustainability Discourse and Action Within Higher Education." Local Environment 22(6): 699-724.

Henderson, J. 2019. "Learning to Teach Climate Change As if Power Matters."

Environmental Education Research 25(6): 987-990.

Henderson, J., D. Long, P. Berger, C. Russell and A. Drewes. 2017. "Expanding the

Foundation: Climate Change and Opportunities for Educational Research." Educational

Studies 53(4): 412-425.

Hodgkins, A. 2010. "Manufacturing (Il)literacy in Alberta's Classrooms." Journal for

Critical Education Policy Studies 8(1): 262-298.

Hope, M. 2017. "BP Greenwashes Image by Pushing 'Blatant Advertising' on

Schoolchildren." DeSmogUK. 26 June.

Horn, M. 1974. Children and Oil. London: British Petroleum Company.

Hursh, D., J. Henderson, and D. Greewood. 2015. "Environmental Education in a Neoliberal

Climate." Environmental Education Research 21(3): 299-318.

Hytten, K., and K. Stemhagen. 2019. "When STEM and STEAM Really Mean ABC."

Educational Studies. DOI: 10.1080/00131946.2019.1579720.

InfluenceMap. 2019. Big Oil's Real Agenda on Climate Change. Washington, DC:

InfluenceMap. 
Kelly, P. 2017. "STEM Deserves an F." Critical Education 8(15): 41-54.

Kennedy-Salchow, S. 2017. Corporate Philanthropy Practices in K-12 Education in the US and Germany. PhD Dissertation, Humboldt University, Berlin.

King, H., E. Nomikou, L. Archer, and E. Regan. 2015. "Teachers' Understanding and Operationalisation of 'Science Capital'." International Journal of Science Education 37(18): 2987-3014.

Klein, N. 2019. On Fire. New York: Penguin.

Lander, R. 2013. Knowledge and Power. London: Platform.

Lawrence, F., and H. Davies. 2015. "BP's Close Ties with the UK Government." Guardian. 21 May.

Lipman, P. 2011. The New Political Economy of Urban Education. New York: Routledge. Lovett, G., C. Lambert, E. Chu, and J. Gupta. 2018. "The Grounding for a Fossil Fuel Free World: Integrating Climate Change Education into Secondary Schools." In Handbook of Climate Change Communication, Vol. 2, edited by W. Filho, E. Manolas, A. Azul, U. Azeiteiro, and H. McGhie, 205-222. Cham: Springer.

Mann, M. 2016. The Madhouse Effect. New York: Columbia University Press.

Manning, S. 1999. "The Corporate Curriculum.” Nation. 27 September: 17.

Marsden, C. 1983. Educational Liaison: Policy and Programme. London: British Petroleum Company.

Marsden, C. 1991. Education and Business: A Vision for the Partnership. Alton: BP Educational Service.

Morgan, R., and C. Kirby. 2016. The UK STEM Education Landscape. London: Royal Academy of Engineering.

Mulvey, K. 2018a. "BP's Hypocrisy on Climate Policy." Union of Concerned Scientists. 19 December.

Mulvey, K. 2018b. "Fossil Fuel Giants are Pumping out Greenwashing." Union of Concerned Scientists. 13 November.

Muttitt, G. 2003. Degrees of Capture: Universities, the Oil Industry and Climate Change. London: Platform.

Nelson, M. 2018. Futureproofing: How ExxonMobil is Helping Tackle America's STEM Workforce Challenges. https://www.nms.org/News-and-Views/News/Futureproofing-HowExxonMobil-is-Helping-Tackle-A.aspx.

Neslen, A. 2015. "BP Tops the List of Firms Obstructing Climate Action in Europe." Guardian. 21 September.

Neslen, A. 2016. "EU Dropped Climate Policies after BP Threat of Oil Industry Exodus." Guardian. 20 April.

Orr, D. 2004, Earth in Mind. Washington: Island Press.

Parkinson, S., and P. Wood. 2019. Irresponsible Science? How the Fossil Fuel and Arms Industries Finance Professional Engineering and Science Organisations. Halton: Scientists for Global Responsibility.

Peters, M., and A. Wals (2016) "Transgressive Learning in Times of Global Systemic Dysfunction." Open Review of Educational Research 3(1): 179-189.

Ronan. 2019. "Teachers to Bring Climate Truth to the Department for Education." Extinction Rebellion. 21 February. https://rebellion.earth/2019/02/21/this-friday-in-london-teachers-tobring-climate-truth-to-the-department-for-education/.

Rowell, A. 2018. "BP and Big Oil Drive Society Over the 'Climate Cliff."' Oil Change International. 19 August.

Royal Academy of Engineering. 2019a. Connecting STEM Teachers. https://www.raeng.org.uk/education/schools/education-programmes/connecting-stemteachers. 
Royal Academy of Engineering. 2019b. Professor Dame Ann Dowling.

https://www.raeng.org.uk/about-us/staff-council-committees/the-president.

Royal Academy of Engineering. 2019c. This is Engineering.

https://www.raeng.org.uk/education/this-is-engineering.

Sainsbury, Lord. 2007. The Race to the Top. London: HM Treasury.

Saltman, K., and R. Goodman. 2003. "Rivers of Fire: BP Amoco's iMPACT on Education."

In Education as Enforcement, edited by K. Saltman and D. Gabbard, 37-59. New York:

RoutledgeFalmer.

Schaeperkoetter, C. 2016. Petro Pete's Big Bad Dream. Oklahoma City: OERB.

Science Museum Group. 2019a. Academy. https://www.sciencemuseumgroup.org.uk/ourservices/academy/.

Science Museum Group. 2019b. Our Approach and Science Capital.

https://www.sciencemuseumgroup.org.uk/our-work/our-approach-and-science-capital/.

Selby, D., and F. Kagawa. 2018. "Teetering on the Brink: Subversive and Restorative

Learning in Times of Climate Turmoil and Disaster." Journal Transformative Education.

DOI: $10.1177 / 1541344618782441$.

Sharma, A. 2016. "The STEM-ification of Education." Journal for Activism in Science and Technology Education 7(1): 24-51.

Simons, M., L. Lundahl, and R. Serpieri. 2013. Special Issue: The Governing of Education in

Europe: Commercial Actors, Partnerships and Strategies. European Education Research

Journal 12(4).

Sukarieh, M., and S. Tannock 2009. "Putting School Commercialism in Context: A Global

History of Junior Achievement Worldwide." Journal of Education Policy 24(6): 769-786.

STEM Learning. 2019a. About Us. https://www.stem.org.uk/about-us.

STEM Learning. 2019b. Our Governance. https://www.stem.org.uk/about-us/ourgovernance.

Tannock, S. 2010. "Learning to Plunder: Global Education, Global Inequality and the Global City." Policy Futures in Education 8(1): 82-98.

Tomei, A., J. Dillon, and E. Dawson. 2015. "United Kingdom: An Example of the Impact of High Stakes Accountability Regimes on STEM Education." In The Age of STEM, edited by B. Freeman, S. Marginson and R. Tytler, 161-177. New York: Routledge.

UCL. 2019. Enterprising Science. https://www.ucl.ac.uk/ioe/departments-andcentres/departments/education-practice-and-society/science-capital-research/enterprisingscience.

UKASDC - UK Association for Science and Discovery Centres. 2019. "Science Capital in

Practice." https://www.sciencecentres.org.uk/projects/science-capital-practice/.

UK Student Climate Network. 2019. We, The Students, Demand... https://ukscn.org/ourdemands/.

Vaughn, A. 2018. “'Lightweight PR and Greenwash' - BP's Low-Carbon Plan Dismissed." Guardian. 16 April.

Waldron, F., B. Ruane, R. Oberman, and S. Morris. 2019. "Geographical Process or Global Injustice? Contrasting Educational Perspectives on Climate Change." Environmental Education Research 25(6): 895-911.

Washburn, J. 2010. Big Oil Goes to College. Washington, DC: Center for American Progress.

Wellcome Trust. 2008. "New $£ 30$ Million Investment to 'Enthuse' the Next Generation of

Scientists.” 12 March. https://wellcome.ac.uk/press-release/new-£30-million-investment-

enthuse-next-generation-scientists.

Wilks, S. 2015. The Revolving Door and the Corporate Colonisation of UK Politics. London: High Pay Centre. 
Williams, J., and S. Choudry. 2016. "Mathematics Capital in the Educational Field: Bourdieu and Beyond." Research in Mathematics Education 18(1): 3-21.

Yanez, G., K. Thumlert, S. de Castell, and J. Jenson. 2019. "Pathways to Sustainable Futures: A 'Production Pedagogy' Model for STEM Education." Futures. DOI:

10.1016/j.futures.2019.02.012.

Ziedler, D. 2016. "STEM Education: A Deficit Framework for the Twenty First Century?" Cultural Studies of Science Education 11(1): 11-26.

Zou, J. 2017. "Oil's Pipeline to America's Schools." Center for Public Integrity. 15 June. https://apps.publicintegrity.org/oil-education/.

Zouda, M. 2016. "Deconstructing STEM: A Reading Though the Postmodern Condition." Journal for Activism in Science and Technology Education 7(1): 70-83. 